\title{
As water is to fish, so is society to people
}

Looking down from a bridge onto a lake with Koi carp, I can see them moving sinuously through the water. Their progress appears natural, effortless. If I could ask the carp, would they be aware that they are swimming in water? I think not. Maybe they would talk about their own ability at swimming, their long hours of practice, that clever signature flick of their tail and never mention the element in which they live. Perhaps fish only become aware of the existence of water when they are taken out of it; are landed gasping on the river bank by a fisherman. Then they realise its importance and know that, if they are not returned within minutes, they will die. So it is for us. People, especially modern people, see themselves as independent actors who forge their own lives, who create their own meaning out of their lives. Yet take a man out of society into solitary confinement and in short order a number will go quite mad. Those who remain sane, and some have survived solitary confinement for years, sometimes do so supported by a sense of the justness of their cause, of a society out there supporting them. Others engage in elaborate rituals of exercise, memory, and prayer to impose order.

We know why water is so important for fish, but why is society so important for people? Clearly we are to a greater extent social beings than modern models might have us think. One reason is that many of things we take for granted are actually social goods. By social goods I mean things that only exist because they, or belief in them, are shared by a whole society. Language, for example is a social good. It only exists, is only useful for communication, because a whole society shares the language. It already exists before we are born; the individual does not create it. We cannot ascribe arbitrary meanings to words. Money is also a social good. Money only has value because individuals in a society share a belief in its value. If they lose this belief (as in societies with hyper-inflation), the value disappears.
Witchcraft in some societies works in exactly the same way, as I learnt when I worked in Central Africa. If all individuals in the society believe in it, then the effects of witchcraft are real. An outsider saying that witchcraft does not exist is as completely ignored as a stranger to England who said that paper money was worthless. Finally, power in most of its forms is again a social good. It depends for its existence on the belief of both the rulers and the ruled. When this belief wanes, revolution becomes possible and those who were powerful can become powerless. (Conversely the power of GPs is largely informal. It is only as we use it on behalf of our patients by writing to housing authorities, benefits agencies, hospitals, and so on that it becomes real. If we do not use it, it withers away.)

If we take seriously this understanding of people as not only incarnate in a body and possessing a mind, but also enmeshed in society, does this have any implications for general practice? If we were to treat this question systematically we would need to consider its implications for the patient, the doctor and his engagement with society and politics. In this essay, however, I only want to mention some random examples. Teaching GP trainees, they often need coaching to elicit the social world of their patients; relationships, occupations, position in society. All GPs need to decide to what extent they will get involved in claims for benefits. This is a particularly topical question right now when the government is aiming to get most people under 50 off long-term incapacity benefit. These people are hitting our consulting rooms on a daily basis because these changes have profound implications for them. The need for a new social network is perhaps most acutely felt by refugees and asylum seekers; I have reviewed their needs for primary care elsewhere. ${ }^{1}$ Other people who need to find a new social group would be recently released prisoners, drug addicts who wish to give up a drug they are used to with its attendant lifestyle and, more prosaically, the depressed, especially those with postnatal depression.

The social nature of people is used therapeutically by a strand of narrative medicine described by John Launer. ${ }^{2}$ Into the consultation between the doctor and the patient, the doctor introduces other people from the patient's social world. For example, where the patient has a longterm partner, it is possible to ask, 'What do you think your partner would say?'. This can break the log-jam in a consultation and at its least can be illuminating. We can find out that the partner thinks that the patient is making a fuss, in which case they may be right; that the partner has not been told, which highlights communication issues; or that the partner has specific health beliefs or anxieties which can then be addressed. For many people in our country today that social world includes God, the creator, and therefore religious and spiritual concerns can be raised in this way.

I would like to give an example of such a consultation which occurred between a junior anaesthetist and a patient many years ago. I think it shows the potential of this consultation technique. The anaesthetic SHO was asked to see an old man on the ward with intolerable pain due to metastatic prostate cancer in the spine. He inserted an epidural and started a local anaesthetic infusion, thus relieving the immediate pain, then began to talk to the old man. It was night and the ward was quiet. It became clear that the old man was heartbroken because he was estranged from his alcoholic daughter. He longed to be reconciled with her before he died, but could see no reasonable prospect for this. $\mathrm{He}$ also felt guilty because he had neglected his God. He felt it was no good turning to God at the end after a lifetime of ignoring him. When asked if he would forgive his daughter if she returned he said that of course he would; the longing could be seen on his face. When asked if he thought God too would forgive him if he turned to him, he burst into tears as this 
point came home to him. As it happens his back pain did not recur although the epidural infusion was taken down. He was reconciled to his daughter who was seen pushing him round the hospital in a wheelchair. Why did the pain not recur? I do not know. Pain is not just a pure sensation, but one that comes, as it were with a meaning attributed from the beginning. Physical interruption of the sensation by an anaesthetic drug can ease the pain, but so can re-attribution of a different meaning. This pain in his mind had something to do with his rift with his daughter. Maybe, with the rift healed, the pain was less of an overwhelming threat. (Examples in daily practice are less dramatic, but we have all seen patients after a heart attack who interpret every ache in their chest which they would previously have ignored, as angina. They will respond to careful listening and reassurance that these sensations have no sinister meaning, but are normal.)

Our view of society will also have an effect on the sort of doctor we strive to be; on the one hand, a doctor who gets involved in the local community, a Doctor Finlay, or at the other extreme, a bureaucratic, Stakhanovite ticker of QOF boxes. Finally, how we view society will have an effect on how keen we are to engage with politics at all levels. If man's very self is embedded in society, is the striving for social justice integral to the role of the doctor?

\section{Gervase Vernon}

\section{REFERENCES}

1. Vernon G, Feldman R, Wamalwa A. Refugees in primary care: from looking after to working together.

http://repository.forcedmigration.org/pdf/?pid=fmo .5929 (accessed 2 Dec 2010)

2. Launer J. Narrative-based Primary Care: a practical guide. Oxford: Radcliffe Medical Press, 2002.

DOI: 10.3399/bjgp11X549144

\section{My life as a heartsink patient: living with chronic pain}

I was like you once. Some patients would literally make my heart sink. Patients with chronic insoluble problems and their general misery often left me feeling exhausted. They seemed to come to clinic just to complain about how fed up they were. Then one day my life changed forever. After a ski trip I developed backache. When self-treatment failed I sought medical advice and ended up having surgery, which has left me with chronic pain. I have gone from being able to run, bike, and climb mountains to struggling with the stairs. There is some variation from day to day, but in the last 6 years there is not a day that I have not had some pain.

I have tried all the medical, psychological, and complementary therapies. None give me more than moderate relief and seemingly insignificant side effects are often as bad as my underlying symptoms. On good days I try and do more, but then spend 2 weeks in agony despite the strong opioids and other medications that I have to take every day. I am constipated, don't sleep, and have put on weight.

Unlike other forms of bereavement, I cannot move on as every day brings a fresh reminder of how awful my life is. I feel guilty that my wife has had to put up with this on a daily basis for 6 years and has given up so many of the things we used to do together. I feel guilty that my children are missing out on family activities due to my disability and worry that they will see my anger or frustration as their fault. I am angry about losing my well-paid career and only managing one and a half days a week with difficulty. But most of all I am just angry that no one can tell me why this has happened to me. I know I am not going to die from this, but I know that it is unlikely to get much better.

What I want from the doctors who treat me is this: sympathy, understanding of how my pain permeates every thread of my life, and honesty. The next time you see a heartsink patient remember this: once they were just like you. Imagine what it would be like to give up everything in your life that gives you pleasure. Our heartsink relationship is a product of my symptoms and your inability to help me. Conventional medical doctrine is that a sufficient knowledge base will allow you to heal. You pride yourself on being a healer and are uncomfortable when you cannot fulfil this role. Acknowledge this, act on it, and please don't just order more tests as a way to get patients out of the room.

\section{Name of author withheld}

DOI: 10.3399/bjgp11X549153 